\title{
THE RELATIONSHIP BETWEEN ACADEMIC STAFF'S PERCEPTIONS OF ORGANIZATIONAL JUSTICE AND ORGANIZATIONAL CITIZENSHIP BEHAVIORS
}

\author{
Bekir BULUC \\ Faculty of Education, Department of Primary Education \\ Gazi University, Ankara, Turkey \\ E-mail: buluc@gazi.edu.tr
}

\begin{abstract}
The purpose of this study is to determine the relationship between academic staff's perceptions of organizational justice and organizational citizenship behaviors. The study sample included 295 academic staff members from eight faculties of a state university in Ankara, which was chosen through random and cluster sampling techniques. Organizational Justice Scale was used in order to determine the level of organizational justice behaviors, whereas Organizational Citizenship Scale was used in order to determine the level of organizational citizenship behaviors of academic staff. Pearson Moment correlation coefficient and regression analysis were used in analyzing the data. The main findings of the study indicated that there is a positive and significant correlation between organizational justice and organizational citizenship behaviors of academic staff.
\end{abstract}

Key words: organizational justice, organizational citizenship, higher education

\section{Introduction}

Although organizational justice is not a newly studied topic in the field of administration in general, it has been neglected in the field of educational administration. For instance, the concepts of justice and accuracy are to be emphasized in schools (Hoy $\&$ Tarter, 2004). Justice perceptions are related to ethical and unethical forms of work behaviors (Jacobs, Belschak, \& Den Hartog, 2014). Organizational justice deals with the employees' justice perception of rewards, outcomes, taking decisions and participating in a decision-making process (Byrne \& Cropanzano, 2001). Organizational citizenship is, on the other hand, individual behaviors, which are volunteer and supportive of the common goals of the organiza- tion. Such behaviors include helpfulness, well-meaning and cooperation among organization members (Organ, 1988 cited in Skarlicki \& Latham, 1995). The aims of such behaviors are to avoid destructive and undesirable acts in the organization and to improve the ability and skills of employees as well the productivity of the organization. There are rare studies, which analyze the relationship between organizational justice and organizational citizenship in the educational setting. Instead, these concepts have been studied in isolation or one of them has been analyzed in terms of its relationship to other concepts, including organizational culture, job satisfaction, bureaucracy, achievement, organizational loyalty, and leadership styles.

When the related literature on management sciences in three decades is reviewed, it is

DOI: $10.21909 /$ sp.2015.01.673 
seen that many research studies have been conducted on, particularly, organizational justice by the researchers. When this research is analyzed, it is seen that some of the studies have focused on only the concept of organizational justice (e.g., Colquitt, Conlon, Wesson, Porter \& Ng, 2001; Guy \& Dipaola, 2008; Harvey \& Haines, 2005; Hoy \& Tarter, 2004; Lambert, Cluse-Tolar, Pasupuleti, Hall \& Jenkins, 2005; Tyler, 1988). Apart from those, other studies have focused on different aspects of organizational justice and the relationships among them. For example, offensive acts (e.g., Özdevecioğlu, 2003), job satisfaction (e.g., Altahayneh, Khasawneh \& Abedalhafiz, 2014; Yelboğa, 2012; Yeşil \& Dereli, 2012; Yıldıım, 2007), organizational trust and performance (e.g., Annamalai, Abdullah \& Alazidiyeen, 2010), nepotistic behaviors (e.g., Polat \& Kazak, 2014), gender (e.g., Simpson \& Kaminski, 2007), and entrepreneurship (e.g., Basım, Meydan \& Şeşen, 2009), all these suggesting that the perception of justice of the individuals affects many variables such as job satisfaction, performance and others.

Organizational Citizenship Behavior (OCB) has become an important construct in the fields of education and manifests a continually increasing interest in academic managerial literature. When the related literature on OCB is reviewed, it becomes apparent that researchers have studied this issue from different aspects. For example, some of the studies have focused on only the concept of OCB (e.g., Basım \& Şeşen, 2006; Celep, Polat, Elbir \& Yapıc1, 2004; Cetin, 2004; Dipaola, Tarter $\&$ Hoy, 2005; Spector \& Che, 2014). In addition, job satisfaction (e.g., Bateman \& Organ, 1983), personality (e.g., Organ, 1994), efficiency (e.g., Podsakoff \& MacKenzie, 1994), performance (e.g., Obamiro, Ogunnaike
\& Osibanjo, 2014; Skarlicki \& Latham, 1995), loyalty and fatigue (e.g., Celep, Sarıdede \& Baytekin, 2005), achievement (e.g., Dipaola $\&$ Hoy, 2005), emotional commitment (e.g., Gürbüz, 2006), bureaucracy (e.g., Karaman, Yücel \& Dönder, 2008), organizational trust (e.g., Akdoğan \& Köksal, 2014), productivity and career (e.g., Bergerona, Ostroffb, Schroedera \& Blockc, 2014), organizational climate (e.g., Clarck, Zickar \& Jex, 2014), and mobbing (e.g., Seçkin \& Demirel, 2014) are also among the different concepts studied. There are some research studies (e.g., Brebels, Cremer \& Dijke, 2014; Burton, Sablynski \& Sekiguchi, 2008; Niehoff \& Moorman, 1993; Polat \& Celep, 2008), which examine the relationship between OCB and organizational justice. The results of these showed mainly that there is a significant relationship between organizational justice and Organizational Citizenship Behavior.

When the above-mentioned research studies are analyzed, we realize that there has been little research done on organizational justice and Organizational Citizenship Behavior in higher education. As a result of that fact, this study attempts to reveal the perceptions of faculty members about both organizational justice and organizational citizenship and to analyze the potential relationship between them.

\section{Organizational Justice}

Organizational justice refers to the extent to which employees perceive workplace procedure, interactions, and outcomes to be fair in nature (Mohamed, 2014). In modern societies, it is common to hear the concepts of fairness, justice and righteousness. Unfair and undeserved behavior towards others has negative effects on them. More specifi- 
cally, unfair and undeserved behavior leads to disappointment, and even offensive acts in people (Lambert et al., 2005). Although there are many variables affecting the performance of employees in organizations, one of the significant variables is the employees' perception about organizational justice. It is natural that the performance of any employee will be higher if $\mathrm{s} / \mathrm{he}$ believes that $\mathrm{s} / \mathrm{he}$ receives fair and respectful treatment in his work setting and the gains $\mathrm{s} /$ he receives are balanced, and s/he has a part in the organizational decision-making process.

In the related literature, organizational justice has been studied mostly under three dimensions, namely distributive justice, procedural justice and interactional justice. These dimensions are briefly explained as follows:

\section{Distributive Justice}

Distributive justice is defined as the evaluation of individuals concerning the rewards and outcomes given to them as a result of the energy they spend working for an organization. Therefore, the perception of the employees concerning the level of justice is based on the energy they allocated in the organization (Mueller, Iverson \& Jo, 1990). The basis of the distributive justice is encompassed by the equality theory developed by Adams. This theory argues that individuals make a comparison between their own gains in the organization and those of others, in order to gain a justice perception about themselves (Burton et al., 2008). Individuals may perceive the outcomes they gained (i.e., income, premium, promotion, social rights) as either fair or unfair. They also make comparisons between their gains and others' gains. As a result of these com- parisons they may think that they have experienced unfairness in the organization. Eventually, such thoughts may affect their attitude, leading to behavioral and attitudinal changes. The basic point in distributive justice involves the thoughts of individuals about the fairness of sources distributed among them (Özdevecioğlu, 2003).

\section{Procedural Justice}

One of the significant classifications concerning procedural justice was developed by Leventhal (Burton et al., 2008). Leventhal's classification is based on six basic criteria as follows: (1) Consistency: It refers to the consistency in behaviors towards employees and the rewards given to them, (2) Be free from bias: It refers to the fact that procedures followed in the organization are free from favoritism and other similar biases, (3) Decision accuracy: It refers to the collection of correct information, and objective and high-quality procedures used in the decision-making process, (4) Correctibility: It refers to the fact that there are opportunities and mechanisms to correct unfair or incorrect decisions, (5) Representation: It refers to the participation of the parties to be affected by the decisions in the decision-making process, (6) Ethicality: It refers to the fact that there is a consensus over general standards of ethics and justice in the decision-making process (Colquitt et al., 2001; Tyler, 1988).

\section{Interactional Justice}

Interactional justice has somewhat different characteristics compared to distributive justice and procedural justice. More specifically, distributive justice refers to the per- 
ceptions of the employees about the fairness of the payments they receive (Calquitt et al., 2001), whereas procedural justice focuses on the perceptions of the employees concerning formal procedures of the organization (Qiu, Qualls, Bohlmann \& Rupp, 2009). Bies and Moag, and Cropanzano and Greenberg argue that interactional justice refers to the employees' perceptions concerning the fairness of the acts during some of the social changes. If employees receive respectful treatment and if they are well informed about the decisions affecting them, their perceptions of justice may significantly improve (Burton et al. 2008).

Following the studies on organizational justice, the next section provides those a description of studies about organizational citizenship.

\section{Organizational Citizenship}

Organizational Citizenship Behaviors are not directly and clearly defined in the formal rewarding system of organizations. However, these behaviors can be regarded as the ones improving the functions of the organizations, which are voluntarily realized. Such behaviors include the voluntarily participation in extra activities in the organization, helping colleagues and novice employees, and adopting and following the norms and procedures of the organization. Therefore, Organizational Citizenship Behaviors have three basic qualities, namely voluntariness, extra roles and activities beyond job requirements (Brief \& Motowidlo, 1986; Dipaola \& Hoy, 2005; Organ \& Ryan, 1995; Organ, 1997). All successful organizations, including schools, have employees who take part in activities beyond job requirements and voluntarily spend their time and energy for the success of the organization (Dipaola \& Hoy, 2005). Organ argues that organizational citizenship has three basic characteristics, which are given as follows: (1) Acts are voluntary, (2) Acts are not directly or clearly rewarded by the formal rewarding system, (3) Acts improve the functions of the organizations (Pond, Nacoste, Mohr \& Rodriguez, 1997).

\section{Dimensions of Organizational Citizen- ship Behaviors}

Studies on organizational citizenship deal with the identification and classification of the dimensions of organizational citizenship. However, there is no common agreement on these dimensions. The most commonly used classifications in this regard are given below:

Organ's classification of the organizational citizenship includes the following five dimensions (Dipaola \& Hoy, 2005): (1) Altruism: Altruism roughly means that an employee voluntarily helps and spends time with novices or his/her colleagues. Altruism generally covers the above acts towards individuals, but the improvement in individuals' performance improves the efficiency of the entire group as well, (2) Conscientiousness: Goes beyond efficient time management and achievement of minimum expectations. Therefore, it refers to employees' performance much better than expectations, (3) Sportsmanship: This refers to avoiding complaints. It is about efficient time management and constructive activities carried out by employees for the benefit of the organization, (4) Courtesy: It is about informing others, reminding them of the significant points to be aware of in order to avoid future problems, and it is also about the efficient use of 
time and opportunities, (5) Civic Virtue: It refers to the voluntary participation of teachers in committees and ceremonies in the school, and through such participation their interest in and contributions to the school are improved (Dipaola \& Hoy, 2005).

Another classification of the behaviors related to organizational citizenship was developed by Graham. This classification includes the following behaviors: (1) Organizational Obedience: Organizational obedience includes being respectful to organized patterns and processes. Responsible citizens accept rational legal authority and follow the laws, (2) Organizational Loyalty: Organizational loyalty goes beyond the narrowly defined helping behaviors and includes those activities, which expand behaviors to include the wellness of the society as a whole, (3) Organizational Participation: Organizational participation refers to the fact that citizens participate in the administration of the society where they live legally, actively and responsibly (Çetin, 2004).

Podsakoff, MacKenzie, Paine and Bachrach (2000) reviewed studies on organizational citizenship and concluded that the following seven types of behaviors are emphasized in these studies: (1) Helping Behavior, (2) Sportsmanship, (3) Organizational Loyalty, (4) Organizational Compliance, (5) Individual Initiative, (6) Civic Virtue, and (7) Self Development.

In short, the organizational justice and organizational citizenship, which are discussed in the current study, have positive effects on the performance of people and on the improvement of their attitudes and behaviors. Therefore, in the presented study, the relationship between organizational justice and organizational citizenship is analyzed.
Aims of the study

The aim of the study is to determine the relationship between organizational justice and organizational citizenship, based on the perceptions of the faculty members. In parallel to this aim, the study tries to answer the following research questions:

1. At what level are the perceptions of the participants about organizational justice and organizational citizenship?

2. How are organizational justice and organizational citizenship related to each other?

3. Is organizational justice a predictor of organizational citizenship?

\section{Method}

\section{Participants}

In deciding about the composition of the sample group in this study, we first determined the number of academic staff members at the Gazi University. Second, the sample group was chosen according to their academic titles by using the cluster sampling technique. Third, using the random technique, it was determined that 295 academic staff members from eight different faculties, based on their academic titles, would be participants in this study. In terms of the gender variable, $39.3 \%(n=116)$ of participants were female and $60.7 \%(n=179)$ of them were male. When looking at the details of the participants in terms of working status, $28.1 \%(\mathrm{n}=$ $83)$ were research assistants, $12.2 \%(\mathrm{n}=36)$ lecturers, $34.6 \%(\mathrm{n}=102)$ assistant professors, $10.2 \%(\mathrm{n}=30)$ associate professors and $14.9 \%(\mathrm{n}=44)$ professors. In terms of marital status, $75 \%(\mathrm{n}=220)$ of the participants were married and $25 \%(\mathrm{n}=75)$ single. The age 
range of the participants is as follows: $22 \%$ $(\mathrm{n}=65)$ of them were 30 year-old or younger, $62 \%(\mathrm{n}=182)$ were at the age between 31 and 50 years, and $16 \%(n=48)$ were 51 years old or older.

\section{Data Collection Tools}

The data of the study were collected through simultaneous administration of two scales. More specifically, the perception of the participants about organizational justice was evaluated by the organizational justice scale developed by Niehoff and Moorman (1993). Their perceptions concerning organizational citizenship behaviors were measured by the organizational citizenship scale developed by Dipaola, Tarter and Hoy(2005).

\section{Organizational Justice Scale}

The Organizational Justice Scale was developed by Niehoff and Moorman (1993). The scale has three dimensions and 20 items, which are answered through a five-point Likert type scale (" 1 " completely disagree "5" completely agree). The first dimension, which concerns distributive justice, is made up of five items. The second one, which is about procedural justice, includes six items and the third one, which is about interactional justice, is made up of nine items.

There were several stages in the present study for providing the reliability of the scale. Firstly, Niehoff and Moorman (1993) gave the necessary permission to adapt the scale into the Turkish language and use it in this research. Secondly, the scale items were translated individually by the researcher and three academicians, who are competent in both Turkish and English. Thirdly, necessary revisions of the scale were made by the researcher in order to prepare the scale for use. In the next stage a pilot study was carried out.

The scale was used in a pilot study with a sample of 105 faculty members, who were different from those participating in the main study, to measure its validity and reliability. Before factor analysis, the KMO and Barlett's tests were carried out in order to reveal the eligibility of the items for the analysis. It was found that the KMO value of the scale was .920 and that of the Bartlett's Test of Sphericity was 2156.860 , df was 190 , and the $p$ value was .000 . These results indicated that the items in the scale were eligible for factor analysis. The results of the factor analysis showed that the scale has three dimensions and the cumulative rate for variance account-

Table 1 Cronbach's alpha reliability coefficients of the scales and their dimensions

\begin{tabular}{llc}
\hline Scale & Dimensions & Cronbach Alpha \\
\hline \multirow{2}{*}{ Organizational justice } & Distributive justice & .8833 \\
& Procedural justice & .9392 \\
\multirow{2}{*}{ Total } & Interactional justice & .9697 \\
Organizational citizenship & & .9595 \\
\hline
\end{tabular}


ability of the scale is found to be $75.299 \%$. The factor loadings of the items in the scale were found to range between .57 and .87 . Table 1 shows the results of the reliability analysis in regard to the dimensions and the scale as a whole. The reliability values for the scale and its dimensions were found to be similar to the original study.

\section{Organizational Citizenship Scale}

The Organizational Citizenship Scale was developed by Dipaola, Tarter and Hoy (2005). A similar procedure for obtaining validity and reliability of the second scale of this research was carried out. Firstly, the necessary permission was obtained from the authors. The original scale was translated into Turkish and given three experts to review the Turkish form in terms of language, content, and the requested corrections were made. The scale is made up of twelve items of which ten are positive and two are negative. All items in the scale are answered through a six-point Likert type scale (" 1 " completely disagree "6" completely agree). The scale was used in a pilot study with a sample of 105 faculty members who were different from those participating in the main study to measure its validity and reliability. Before the factor analysis, the KMO and Barlett's tests were carried out in order to reveal the eligibility of the items for the analysis. It was found that the KMO value of the scale was .853, that of the Bartlett's Test of Sphericity was 670.561, $\mathrm{df}$ was 66 and the value of $\mathrm{p}$ was .000 . These results indicated that the items in the scale were eligible for the factor analysis. The results of the factor analysis showed that the scale has only one dimension and its cumulative variance accountability is $48.251 \%$. The factor loadings of the items were found to range between .48 and .86. The Cronbach Alpha coefficient of the scale was found to be .899 as can be seen in Table 1 .

\section{Data Analysis}

The data collected were analyzed using the arithmetical mean, standard deviation (s), frequency (f), percentage (\%), the Pearson Moment two-way correlation analysis (r) and multi-regression analysis.

\section{Results}

The arithmetical means and standard deviations concerning the participants' answers to the scales of the organizational justice and organizational citizenship were calculated. The related results are given in Table 2.

As seen in Table 2, for the scale of organizational justice as whole the arithmetical mean was found to be $M=2.87$. In regard to the dimensions of this scale, the highest arithmetical mean was found for the dimension of interactional justice $(M=2.91)$. The lowest arithmetical mean was found for the dimension of procedural justice $(M=2.59)$. The arithmetical mean value for the dimension of distributive justice was between those of the other two dimensions, namely $M=2.87$. The arithmetical mean of the participants' answers to the scale of organizational citizenship was found to be $M=3.81$. These results indicate that the participants perceive the quality of the behaviors towards themselves (interactional justice) and the rewards and gains they are given as a result of their energy they spend for the organization (distributive justice) at an average level. However, the level of their perceptions about the procedures used in the school is lower, indicating that 
they regard these procedures as insufficient. Their perception about the organizational justice is again near the average level. The level of the participants' perceptions about organizational citizenship is found to be near the higher levels. Therefore, it is safe to argue that they appear to like the organization at which they are working and that they make sacrifices for the organization when it is necessary, although there are some negative events.

After these analyses the correlation between the dimensions of the organizational justice and the organizational citizenship behaviors was analyzed through the Pearson two-way correlation analysis. The results of this analysis are given in Table 3.
As shown in Table 3, the highest correlation exists between the dimension of procedural justice and organizational citizenship $(r=.396, p<.01)$. It is followed by the correlation between organizational citizenship and interactional justice $(r=.387, p<$ $.01)$ and between organizational citizenship and distributive justice $(r=.321, p<.001)$. On the other hand, the general correlation between organizational justice and organizational citizenship is positive, average and statistically significant. Based on these findings it is safe to claim that when the perceptions of the faculty members in regard to organizational justice become higher, their organizational citizenship behaviors are also increased.

Table 2 Arithmetical means and standard deviations concerning the participants' answers in the scales of Organizational Justice and Organizational Citizenship

\begin{tabular}{llccc}
\hline Scales & Dimensions & $n$ & $M$ & $S D$ \\
\hline \multirow{3}{*}{ Organizational justice } & Distributive justice & 295 & 2.87 & .96 \\
& Procedural justice & 295 & 2.59 & 1.01 \\
& Interactional justice & 295 & 2.91 & 1.03 \\
\hline \multicolumn{2}{c}{ Organizational citizenship } & 295 & 2.79 & .87 \\
\hline
\end{tabular}

Table 3 Correlations between dimensions of Organizational Justice Scale and Scale of Organizational Citizenship

\begin{tabular}{llccc}
\hline Scales & & 2 & 3 & 4 \\
\hline \multirow{3}{*}{ Organizational justice } & (1) Distributive justice & $.626^{* *}$ & $.544^{* *}$ & $.321^{* *}$ \\
& (2) Procedural justice & & $.760^{* *}$ & $.396^{* *}$ \\
& (3) Interactional justice & & & $.387^{* *}$ \\
\hline Organizational citizenship & (4) Organizational citizenship & & \\
\hline$* * p<.01$ & & & &
\end{tabular}


Table 4 The results of the multi-regression analysis - effect of prediction level of the Organizational Justice on the Organizational Citizenship behaviors

\begin{tabular}{lcccccccc}
\hline Variables & $B$ & $\begin{array}{c}\text { Standard } \\
\text { Error }_{B}\end{array}$ & $\mathrm{~B}$ & $t$ & $p$ & $\begin{array}{c}\text { Zero } \\
\text { Order }\end{array}$ & $\begin{array}{c}\text { Partial } \\
r\end{array}$ \\
\hline Constants & 2.589 & .171 & & 15.145 & .000 & & \\
1 Distributive justice & .096 & .067 & .099 & 1.436 & .152 & .321 & .084 \\
2. Procedural justice & .178 & .082 & .192 & 2.166 & .031 & .396 & .126 \\
3. Interactional justice & .169 & .074 & .188 & 2.281 & .023 & .387 & .133 \\
\hline$R=.425$ & $R^{2}=.181$ Adjusted $R^{2}=.172$ & $F_{(3-291)}=21.367$ & $p=.000$ & & \\
\hline$p<.01$ &
\end{tabular}

Multi-regression analysis was employed to determine the effect of prediction level of organizational justice on organizational citizenship behaviors. The results of this analysis are given in Table 4.

The results of the regression analysis given in Table 4 indicate that there is a positive, average and statistically significant correlation between the dimension of organizational justice and organizational citizenship $\left(R=.425, R^{2}=.181, p<.01\right)$. Three dimensions of organizational justice are found to account for $17 \%$ of the total variance. The standardized regression coefficient $(\beta)$ indicated that the predictive power of the dimensions of organizational justice about organizational citizenship has the following priority rank: procedural justice, interactional justice and distributive justice. The results of t-test carried out in order to reveal the significance of the predictive power of the dimensions of organizational justice indicated that both dimensions, namely procedural justice and interactional justice, have predictive power in terms of organizational citizenship at the level of .05. However, distributive justice does not have any significant predictive power in regard to the prediction of organizational citizenship.

The regression analysis produced the following mathematical model or regression equivalence in regard to the prediction power of the dimensions of organizational justice in terms of organizational citizenship: Organizational Citizenship $=2.589+0.178$ procedural justice +0.169 interactional justice + 0.960 distributive justice.

\section{Discussion}

Research results show that the perceptions of academic staffs of organizational justice are found to be at an average level. When the results concerning sub-dimensions of the scale are analyzed, it is seen that the highest mean score belongs to interactional justice, while the lowest mean score belongs to procedural justice. As argued by Qiu et al. (2009), interactional justice emphasizes the employees' perceptions about the informal acts they come across during the implementation of the procedures in the organization. 
Such acts include the openness of the organizational communication, valuing of employees, and being respectful towards them. In other words, employees are much happier and have higher levels of organizational justice perceptions when they are informed about the workings of the organization and when the administrators respect them. In this context, the findings suggest that the participants have little problem in regard to organizational justice, especially about interactional justice. As stated earlier, procedural justice is about the employees' perceptions of the fairness of the distribution of rewards and also, of the existence of clearly defined norms related to the distribution of rewards (Burton et al., 2008). In addition, in order for employees to have higher levels of procedural justice, the procedures should encourage the participation of employees in the decision-making process or should eliminate or reduce biases and inappropriate decisions (Niehoff \& Moorman, 1993). However, the findings obtained also indicate that the participants are not totally satisfied with the distribution of rewards and with their participation in the decision-making process. Therefore, it can be suggested that the process of the distribution of rewards and the decisionmaking process should be expanded to make it possible for employees to take part in them and to improve the perceptions of these processes.

The findings by Altahayneh et al. (2014), Annamalai et al. (2010), Basım et al. (2009), Hoy and Tarter (2004), Niehoff and Moorman (1993), Polat and Kazak (2014) and Yeșil and Dereli (2012) suggest that when the employees' perceptions about organizational justice is higher, many variables such as organizational citizenship, job satisfaction, organizational loyalty, performance and organiza- tional trust are positively affected. Thus, organizational justice is a very significant contributor of the organizational citizenship behavior of the employees.

The findings of the study in regard to organizational citizenship indicate that the perceptions of the participants in relation to organizational citizenship are higher. As stated earlier, organizational citizenship behaviors are generally those which are voluntary. When people do something voluntarily, it has mostly positive outcomes. The findings by Akdoğan and Köksal (2014), Celep et al. (2005), Clarck et al. (2014), Gürbüz (2006), Obamiro et al. (2014) and Seçkin and Demirel (2014) suggest that organizational citizenship is related to organizational justice as well as to organizational loyalty, burn-out levels of the employees, organizational belonging, employee performance and other similar variables. Therefore, higher levels of the employees' perceptions in regard to organizational citizenship are significant for the organizations, including educational institutions. Therefore, it is an expected result that activities of organizational justice have positive effects on organizational citizenship and that these activities also improve the employees' performance and achievement.

The analysis of the relationship between the dimensions of organizational justice and organizational citizenship indicates that all dimensions of organizational justice have positive and significant correlations with organizational citizenship. However, not all dimensions have equal correlation with organizational citizenship. Of the three dimensions, the one with the highest correlation is the dimension of procedural justice. The one with the lowest correlation with organizational citizenship is found to be the dimension of distributive justice. These findings 
suggest that organizational citizenship behavior of the employees can be improved if they behave in an unbiased, consistent and ethical manner, and if they are allowed to participate in the decision-making process. Given that the correlation between the dimension of distributive justice and organizational citizenship is lower, the participants have experienced some problems in appreciating the rewards and gains they were given compared to the energy they spent for the organization. It is certain that such problems could lead to negative effects on their organizational citizenship behaviors and also, to the lack of improvement of such behaviors. As stated by Y1ldırım (2007), people take into account whether or not outcomes are ethical while evaluating distributive justice. Therefore, activities related to distributive justice should be improved, since this dimension is among the significant factors in organizational citizenship behaviors.

The results of t-test carried out in order to reveal the significance of the predictive power of the dimensions of organizational justice indicated that both dimensions, namely procedural justice and interactional justice, have predictive power in terms of organizational citizenship at the level of .05 . However, distributive justice does not have any significant predictive power in regard to the prediction of organizational citizenship.

\section{Conclusion}

As we can see, both organizational justice and organizational citizenship behaviors are significant for the employees' performance and achievement. The feeling of justice is important for both citizens and educational staff. It is natural and certain that those employees who believe that they have behaved in a fair manner have much more positive attitudes towards their job, working environment, administrators and colleagues. Organizational citizenship behaviors, on the other hand, include those acts, which are voluntarily carried out, such as helping others, liking the job, and attempts to protect organizations in risky conditions. The management of organizations based purely on norms and procedures is not a desired option for them to be successful in the current period in which competition is very strong. The recent advances in the field of education have led to a competitive atmosphere for universities. These institutions have been trying to have a good position among others through research activities, high-quality publications and projects. However, all such activities require those employees who have the necessary qualities and devotedly work towards these ends. In order for universities to take part and to be successful in this highly competitive atmosphere there should be a fair working setting and higher levels of organizational citizenship behaviors of the faculty members.

Based on the findings of this study, we have the following suggestions about the improvement of both organizational justice and organizational citizenship behaviors at the universities in Turkey. First of all, faculty members should be allowed to participate in the decision-making process in an efficient way, because such a participation has positive effects on the acts of faculty members in the implementation of these decisions. In addition, faculty and departmental administrators should behave consistently and fairly. In order to improve the organizational citizenship behaviors of faculty members, they should be offered opportunities to develop their potentials, to assume responsibilities. 
Additionally, innovative activities of the faculty members should be supported and an efficient communication system should be established.

Received July 10, 2014

\section{References}

Akdoğan, A. A., \& Köksal, O. (2014). Aidiyet algısının örgütsel vatandaşlık davranışı üzerindeki etkisinde yöneticiye güvenin aracılık rolü. [The mediation role of trust in supervisor on the relationship between insider perception and organizational citizenship behavior]. Atatürk Üniversitesi Sosyal Bilimler Enstitüsü Dergisi, 18(1), 25-43.

Altahayneh, Z. L., Khasawneh, A., \& Abedalhafiz, A. (2014). Relationship between organizational justice and job satisfaction as perceived by Jordanian physical education teachers. Asian Social Science, 10(4), 131-138.

Annamalai, T., Abdullah, A. G. K., \& Alazidiyeen, N. J. (2010). The mediating effects of perceived organizational support on the relationships between organizational justice, trust and performance appraisal in Malaysian secondary schools. European Journal of Social Sciences, 13(4), 623632.

Basim, H. N., \& Şeşen, H. (2006). Örgütsel vatandaşlık davranışı ölçeği uyarlama ve karşılaştırma çalışması. [An adaptation and comparison of organizational citizenship behavior scale]. Ankara Üniversitesi Siyasal Bilgiler Fakültesi Dergisi, 61(4), 83-102.

Basim, H. N., Meydan, C. H., \& Şeșen, H. (2009). Bireyin örgütsel adalet algısının iç girișimcilik davranışı ile ilişkisi: Kamuda bir araştırma. [The relationship between organizational justice perception and entrepreneurship behavior: A study in the public sector]. İktisat, Issletme ve Finans, 24, 79-99.

Bateman, T. S., \& Organ, D. W. (1983). Job satisfaction and the good soldier: The relationship between affect and employee citizenship. Academy of Management Journal, 26, 587-595.

Bergerona, D., Ostroffb, C., Schroedera, T., \& Blockc, C. (2014). The dual effects of organizational citizenship behavior: Relationships to research productivity and career outcomes in academe. Human Performance, 27, 99-128.
Brebels, L., Cremer, D. D., \& Dijke, M. V. (2014). Using self-definition to predict the influence of procedural justice on organizational-, interpersonal-, and job/task-oriented citizenship behavior. Journal of Management, 40(3), 731-763.

Brief, A. P., \& Motowidlo, S. J. (1986). Prosocial organizational behaviors. Academy of Management Review, 11(4), 710-725.

Burton, J. P., Sablynski, C. J., \& Sekiguchi, T. (2008). Linking justice, performance, and citizenship via leader-member exchange. Journal of Business and Psychology, 23, 51-61.

Byrne, Z. S., \& Cropanzano, R. (2001). The history of organizational justice: The Founders Speak. In R. Cropanzano (Ed), Justice in the Workplace: From Theory to Practice. Vol. 2 (pp. 3-26). Lawrence Erlbaum Associates, Inc.

Celep, C., Polat, S., Elbir, N., \& Yapici, E. (2004, Temmuz). Ortaöğretim okullarındaki ögretmenlerin örgütsel vatandaşlık tutumlarl. [Organizational citizenship behaviors of secondary school teachers]. XIII. Ulusal Eğitim Bilimleri Kurultayl, İn̈̈nü Üniversitesi, Ĕ̆itim Fakültesi, Malatya.

Celep, C., Saridede, U., \& Baytekin, F. (2005, Eylül). Eğitim örgütlerinde örgütsel bağlllık, örgütsel vatandaşlık davranışı ve tükenmişlik arasındaki ilişki. [The relationship between organizational commitment, organizational citizenship and burnout in educational institutions]. XIV. Ulusal Eğitim Bilimleri Kongresi. Pamukkale Üniversitesi Eğitim Fakültesi, Denizli.

Clark, O. L., Zickar, M. J., \& Jex, S. M. (2014). Role definition as a moderator of the relationship between safety climate and organizational citizenship behavior among hospital nurses. Journal of Business and Psychology, 29, 101-110.

Colquitt, J. A., Conlon, D. E., Wesson, M. J., Porter, C. O. L. H., \& Ng, K. Y. (2001). Justice at the millennium: A meta-analytic review of 25 years of organizational justice research. Journal of Applied Psychology, 86(3), 425-445.

Çetin, M. (2004). Örgütsel Vatandaşlık Davranışı [Organizational Citizenship Behaviors]. Ankara: Nobel Yayın Dağıtım.

Dipaola, M. F., \& Hoy, W. K. (2005). Organizational citizenship of faculty and achievement of high school students. The High School Journal, 88(3), 35-44.

Dipaola, M. F., Tarter, C. J., \& Hoy, W. K. (2005). Measuring organizational citizenship of schools: The OCB scale. In W. Hoy, C. Miskel (Eds.), Educational Leadership and Reform, 4, (pp. 319- 
341). Greenwich, CN: Information Age Publishing.

Guy, S., \& Dipaola, M. (2008, October). Organizational justice in high schools: A study of its relationship to school climate and faculty trust. $\mathrm{Pa}$ per presented at the annual meeting of the UCEA Annual Convention, Buena Vista Palace Hotel and Spa, Florida. Retrieved from http://citation. allacademic.com/meta/p274815_index.html.

Gürbüz, S. (2006). Örgütsel vatandaşlık davranışı ile duygusal bağlılık arasındaki ilişkilerin belirlenmesine yönelik bir araştırma [A research on identifying the relationships between organizational citizenship behavior and affective commitment]. Ekonomik ve Sosyal Araştırmalar Dergisi, 3(2), 48-75.

Harvey, S., \& Haines, V. Y. (2005). Employer treatment of employees during a community crisis The role of procedural and distributive justice. Journal of Business and Psychology, 20(1), 5368.

Hoy, W. K., \& Tarter, C. J. (2004). Organizational justice in schools: No justice without trust. International Journal of Educational Management, 18(4), 250-259.

Jacobs, G., Belschak, F. D., \& Den Hartog, D. N. (2014). (Un) Ethical behavior and performance appraisal: The role of affect, support, and organizational justice. Journal of Business Ethics, 121, 63-76.

Karaman, K., Yücel, C., \& Dönder, H. (2008). Öğretmen görüşlerine göre, okullardaki bürokrasi ile örgütsel vatandaşlık arasındaki ilişki [The relationships between bureaucracy and organizational citizenship behaviors in elementary schools based on teachers' perceptions]. Kuram ve Uygulamada Ĕgitim Yönetimi, 53, 49-74.

Lambert, E. G., Cluse-Tolar, T., Pasupuleti, S., Hall, D. E., \& Jenkins, M. (2005). The impact of distributive and procedural justice on social service workers. Social Justice Research, 18(4), 411 427.

Mohamed, S. A. (2014). The relationship between organizational justice and quality performance among healthcare workers: A pilot study. The Scientific World Journal. Retrieved from http:// dx.doi.org/10.1155/2014/757425.

Mueller, C., Iverson, R., \& Jo, D. (1999). Distributive justice: Evaluations in two cultural contexts: A comparison of U.S. and South Korean teachers. Human Relations, 52(7), 869-893.

Niehoff, B. P., \& Moorman, R. H. (1993). Justice as a mediator of the relationship between meth- ods of monitoring and organizational citizenship behavior. Academy of Management Journal, $36(3), 527-556$.

Obamiro, J. K., Ogunnaike, O. O., \& Osibanjo, O. A. (2014). Organizational citizenship behaviour, hospital corporate ýmage and performance. Journal of Competitiveness, 6(1), 36-49.

Organ, D. W. (1994). Personality and organizational citizenship behavior. Journal of Management, 20(2), 465-478.

Organ, D. W. (1997). Organizational citizenship behavior: It's construct clean-up time. Human Performance, 10(2), 85-97.

Organ, D. W., \& Ryan, K. (1995). A meta analytic review of attitudinal and dispositional predictors of organizational citizenship behavior. Personal Psychology, 48, 775-802.

Özdevecioğlu, M. (2003). Algilanan örgütsel adaletin bireylerarası saldırgan davranışlar üzerindeki etkilerinin belirlenmesine yönelik bir araştırma [A study: The effects of perceived organizational justice behaviors on aggressive behaviors]. Erciyes Üniversitesi Íktisadi ve İdari Bilimler Fakültesi Dergisi, 21, 77-96.

Podsakoff, P. M., \& Mackenzie, S. B. (1994). Organizational citizenship behaviors and sales unit effectiveness. Journal of Marketing Research, 31(3), 351-363.

Podsakoff, P. M., Mackenzie, S. B., Paine, J. B., \& Bachrach, D. G. (2000). Organizational citizenship behaviors: A critical review of the theoretical and empirical literature and suggestions for future research. Journal of Management, 26(3), 513-563.

Polat, S., \& Celep, C. (2008). Ortaöğretim öğretmenlerinin örgütsel adalet, örgütsel güven, örgütsel vatandaşlık davranıșlarına ilişkin algıları [Perceptions of secondary school teachers on organizational justice, organizational trust, organizational citizenship behaviors]. Kuram ve Uygulamada Eğitim Yönetimi Dergisi, 54, 307331.

Polat, S., \& Kazak, E. (2014). Okul yöneticilerinin kayırmacı tutum ve davranışları ile öğretmenlerin örgütsel adalet algıları arasındaki ilişki [The correlation between school principals' favoritist behaviors and attitudes and teachers' perception of organizational justice]. Kuram ve Uygulamada Eğitim Yönetimi Dergisi, 20(1), 7192.

Pond, S. B., Nacoste, R. W., Mohr, M. F., \& Rodriguez, C. M. (1997). The measurement of 
organizational citizenship behavior: Are we assuming too much?. Journal of Applied Social Psychology, 27(17), 1527-1544.

Qiu, T., Qualls, W., Bohlmann, J., \& Rupp, D. (2009). The effect of interactional fairness on the performance of cross-functional product development teams: A multi-level mediated model. Journal of Product Innovation Management, 26, 173-187.

Seçkin, Z., \& Demirel, Y. (2014). Çalışanların örgütsel adalet algıları ile psikolojik yıldırma davranışı (mobbing) arasındaki ilişki [The relationship between the employees' organizational justice perceptions and mobbing behavior] Atatürk Üniversitesi Sosyal Bilimler Enstitüsü Dergisi, 18(1), 329-348.

Simpson, P. A., \& Kaminski, M. (2007). Gender, organizational justice perceptions, and union organizing. Employ Respons Rights Journal, 19 57-72.

Skarlicki, D. P., \& Latham, G. P. (1995). Organizational citizenship behavior and performance in university setting. Canadian Journal of Administrative Sciences, 12(3), 175-181.
Spector, P. E., \& Che, X. X. (2014). Re-examining citizenship: How the control of measurement artifacts affects observed relationships of organizational citizenship behavior and organizational variables. Human Performance, 27, 165-182.

Tyler, T. (1988). What is procedural justice?: Criteria used by citizens to assess the fairness of legal procedures. Law and Society Review, 22(1), 103-135.

Yelboğa, A. (2012). Örgütsel adalet ile iş doyumu ilişkisi: Ampirik bir çalışma [The relationship between organizational justice and job satisfaction: An empirical study]. Ege Akademik Bakış, 12(2), 171-182.

Yeşil, S., \& Dereli S. F. (2012). Örgütsel adalet ve is tatmini üzerine bir alan çalışması [A field study on organizational justice and job satisfaction]. Kahramanmaraş Sütçü İmam Üniversitesi İktisadi ve İdari Bilimler Fakültesi Dergisi, 2(1), 105122.

Yıldırım, F. (2007). İș doyumu ile örgütsel adalet ilişkisi [The relationship between organizational justice and job satisfaction]. Ankara Üniversitesi SBF Dergisi, 62(1), 253-278.

\title{
VZŤAH MEDZI VNIIMANÍM SPRAVODLIVOSTIV ORGANIZÁCII A PRÍSLUŠNOSŤOUK ORGANIZÁCII U AKADEMICKÝCH ZAMESTNANCOV
}

\author{
B. B u 1 u c
}

Súhrn: Zámerom štúdie je zistit' vzt’ah medzi vnímaním spravodlivosti v organizácii a príslušnost'ou k organizácii u akademických zamestnancov. Výskumu sa zúčastnilo 295 členov akademického zboru z ôsmich fakúlt štátnej univerzity v Ankare, ktorí boli vybraní na základe náhodného a klastrového výberu. Použili sme Organizational Justice Scale na určenie úrovne spravodlivosti v organizácii, na určenie príslušnosti k organizácii akademického zboru sme použili Organizational Citizenship Scale. Dáta sme analyzovali pomocou Pearsonovho korelačného koeficientu a regresnej analýzy. Z výsledkov štúdie vyplýva, že medzi spravodlivot'ou v organizácii a príslušnost'ou $\mathrm{k}$ organizácii akademického zboru je pozitívna a signifikantná korelácia. 